\title{
VOLUTA UNDULATA.
}

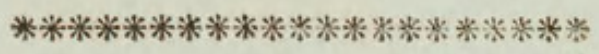

CHARACTER GENERICUS.

Animal Limax.

Testa unilocularis, spiralis.

Apertura ecaudata, subeffusa.

Columella plicata.

Lin. Syst. Nat. p. 1195.

CHARACTER SPECIFICUS, छัC.

VOLUTA gilvo-flavescens, glabra, lineis longitudinalibus flexuosis fusco-purpureis, columella quadriplicata.

VOLUTA UNDULATA. V. ovato-fusiformis lævigata submaculosa, lineis fuscis longitudinalibus undatim flexuosis picta; columella quadriplicata.

Lamarck, Ann. Mus. Hist. Nat. No. 27. p. $157 \cdot$ pl. 12. f. 1,2 .

Maria Antarctica, præcipue circa litora Australasiæ incolit rara hæc Volutæ species, magnitudine vera in tabula depicta. 

, 
702
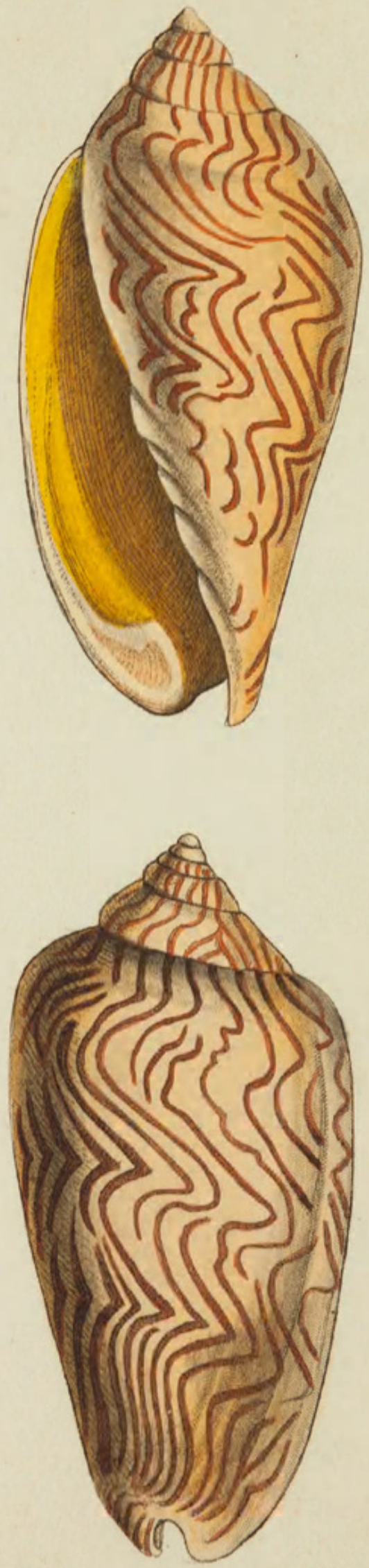

$22 \sqrt{ }=D_{0}<+3$ bunt 


\section{UNDULATED VOLUTE.}

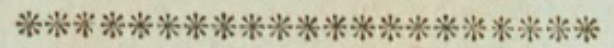

GENERIC. CHARACTER.

Animal resembling a Limax or Slug. Shell unilocular, spiral.

Aperture somewhat spreading, simple. Pillar wreathed or pleated.

SPECIFIC CHARACTER, E'c.

Dull-ycllow smooth VOLUTE, with longitudinal, flexuose, purple-brown lines, and four-pleated pillar.

VOLUTE ondulée.

Lamarck, Ann. Mus. Hist. Nat. No. 27.

The present species of Volute is a native of the Antarctic seas, and is principally found about the coasts of Australasia. It is represented in its natural size. 


\section{$2 \mathrm{BHL}$ Biodiversity Heritage Library}

Shaw, George. 1806. "The Undulated Volute, Voluta Undulata [PI. 702]." The Naturalist's Miscellany 17(CCII), https://doi.org/10.5962/p.311139.

View This Item Online: https://www.biodiversitylibrary.org/item/281954

DOI: https://doi.org/10.5962/p.311139

Permalink: https://www.biodiversitylibrary.org/partpdf/311139

\section{Holding Institution}

Museums Victoria

\section{Sponsored by}

Atlas of Living Australia

\section{Copyright \& Reuse}

Copyright Status: Public domain. The BHL considers that this work is no longer under copyright protection.

This document was created from content at the Biodiversity Heritage Library, the world's largest open access digital library for biodiversity literature and archives. Visit BHL at https://www.biodiversitylibrary.org. 